\title{
Combustion Stratification for Naphtha from CI Combustion to PPC
}

R. Vallinayagam, S. Vedharaj, Yanzhao An, and Alaaeldin Dawood

King Abdullah University of Science and Technology

\section{Mohammad Izadi Najafabadi and Bart Somers}

Eindhoven University Of Technology

\section{Bengt Johansson}

King Abdullah University of Science and Technology

CITATION: Vallinayagam, R., Vedharaj, S., An, Y., Dawood, A. et al., "Combustion Stratification for Naphtha from CI Combustion to PPC," SAE Technical Paper 2017-01-0745, 2017, doi:10.4271/2017-01-0745.

Copyright (C) 2017 SAE International

\begin{abstract}
This study demonstrates the combustion stratification from conventional compression ignition (CI) combustion to partially premixed combustion (PPC). Experiments are performed in an optical $\mathrm{CI}$ engine at a speed of $1200 \mathrm{rpm}$ for diesel and naphtha $(\mathrm{RON}=46)$. The motored pressure at TDC is maintained at 35 bar and fuelMEP is kept constant at 5.1 bar to account for the difference in fuel properties between naphtha and diesel. Single injection strategy is employed and the fuel is injected at a pressure of 800 bar. Photron FASTCAM SA4 that captures in-cylinder combustion at the rate of 10000 frames per second is employed. The captured high speed video is processed to study the combustion homogeneity based on an algorithm reported in previous studies.
\end{abstract}

Starting from late fuel injection timings, combustion stratification is investigated by advancing the fuel injection timings. For late start of injection (SOI), a direct link between SOI and combustion phasing is noticed. At early SOI, combustion phasing depends on both intake air temperature and SOI. In order to match the combustion phasing (CA50) of diesel, the intake air temperature is increased to $90^{\circ} \mathrm{C}$ for naphtha. The combustion stratification from CI to PPC is also investigated for various level of dilution by displacing oxygen with nitrogen in the intake. The start of combustion (SOC) was delayed with the increase in dilution and to compensate for this, the intake air temperature is increased. The mixture homogeneity is enhanced for higher dilution due to longer ignition delay. The results show that high speed image is initially blue and then turned yellow, indicating soot formation and oxidation. The luminosity of combustion images decreases with early SOI and increased dilution. The images are processed to generate the level of stratification based on the image intensity. The level of stratification is same for diesel and naphtha at various SOI. When $\mathrm{O}_{2}$ concentration in the intake is decreased to $17.7 \%$ and $14.7 \%$, stratification level is decreased. $\mathrm{NO}_{\mathrm{X}}$ emission for both diesel and naphtha show a decreasing trend from CI to PPC.
Comparing diesel and naphtha, the soot emission is lower for naphtha. $\mathrm{NO}_{\mathrm{X}}$ and soot emissions at various SOI are correlated with high speed images of combustion to explain the combustion stratification.

\section{Keywords}

Naphtha, stratification, combustion homogeneity, PPC, optical CI engine

\section{Introduction}

Partially premixed combustion (PPC) is intermediate between compression ignition (CI) and homogeneous charge compression ignition (HCCI) that offers a better control of combustion due to increased stratification $[\underline{1}, \underline{2}, \underline{3}, \underline{4}]$, compared to HCCI. In conception, increasing the delay time between start of ignition (SOI) and start of combustion (SOC) make the combustion homogenous [ [ ] ]. While combustion phasing is sensitive to SOI in CI combustion, it is dependent on intake air temperature for HCCI. Since PPC is in between HCCI and CI combustion concepts, combustion phasing is expected to be governed by both intake air temperature and SOI. Therefore, it is worth of an investigation to study the transition from CI to PPC by varying the intake air temperature and SOI to gain more insights on combustion homogeneity and stratification.

Many studies report the transition to PPC and HCCI from CI combustion in metal CI engine [ $[\underline{6}, \underline{7}]$. Recently, in-cylinder diagnostics of combustion homogeneity and stratification of air/fuel mixture are studied in an optical CI engine. A study reports achieving PPC by advancing SOI and increasing the dilution level and intake temperature [ $\underline{8}]$. High speed image of the combustion process was studied for PRF70 and the work elucidated the combustion homogeneity based on image luminosity. Another study concedes that high level of dilution, pilot injections and increased fuel injection pressure influences PPC in an optical CI engine [9]. With dilution, the radial flame distribution was promoted and $\mathrm{C}_{2}$ imaging indicated that 
higher level of dilution enhance premixing so that combustion homogeneity is improved. A recent study varied the oxygen concentration in the intake and fuel composition is changed to analyze the effect of ignition delay on PPC [1이. High speed imaging of chemiluminescence from $\mathrm{OH}^{*}$ identified the edge of flame and a correlation between ignition delay and flame positioning is reported.

Chemiluminescence gives a holistic view on the combustion stratification inside the combustion chamber [11]. Based on Chemiluminescence and high speed imaging, the effect of fuel injection strategies on combustion stratification was investigated for PRF55 [9]. Implementing negative value overlap (NVO) strategy that retains residual gases in the combustion chamber, combustion stability was maintained. The study concluded that degree of stratification decreased with the advancement in fuel injection timing and combustion is more homogenous for triple injection when compared to single or double injection. In an advanced study, the ignition sensitivity of PPC to SOI at different fuel injection pressures was studied [12]. This study proposed a method to estimate combustion stratification wherein the image intensity is averaged both radially and angularly. The $\mathrm{OH}^{*}$ Chemiluminescence images showed more homogenous combustion for early SOI. The study concludes that combustion stratification was lower for early SOI and higher for late SOI, identifying SOI as crucial factor for controlling stratification. Also, lower fuel injection pressure lead to more stratified combustion, while higher injection pressure resulted in more homogenous combustion.

The above literature study shows that PPC can be achieved by advancing the SOI, increasing the dilution in intake and decreasing the compression ratio. Combustion becomes homogenous with advanced SOI and increased dilution levels, whereas increasing the intake air temperature supports auto-ignition. While SOI is a decisive factor that affects combustion phasing, fuel octane number also proves crucial $[13,14]$. The use of gasoline like fuels in CI engine enables in achieving PPC or HCCI and reduces the emissions [15]. While gasoline and PRF's were tested, naphtha is also considered for PPC studies in CI engine. Given the lower cetane number $(\mathrm{CN})$ of naphtha, operation of naphtha in $\mathrm{CI}$ engine requires modifications with engine to support its auto ignition. A recent study reports optimization of combustion bowl geometry and nozzle hole geometry to adapt naphtha in CI engine $[\underline{16}, \underline{17}]$. Similarly, to achieve combustion stability with naphtha, fuel injection strategy is also a viable technique [18]. Double injection strategy with single and two stage heat release reportedly increased the efficiency and reduced the emissions for naphtha.

In this research work, combustion stratification from conventional CI combustion to PPC is studied. The SOI is swept from late (-10 CAD aTDC) to early ( $-30 \mathrm{CAD}$ aTDC) fuel injection timings and the point where SOI decouples with combustion phasing is identified. The experiment is performed in a single cylinder optical CI engine for diesel and naphtha. Most of the studies on naphtha are reported in metal engine; combustion process of naphtha using high-speed imaging is rarely investigated thus far. Therefore, it is noteworthy to study the combustion stratification for naphtha in an optical CI engine. The experiments are also performed at various levels of dilution and increased intake air temperature. A high speed video of the combustion process is recorded through an optical piston from the bottom and the images are correlated with in-cylinder pressure and rate of heat release. Also, the combustion images are compared between diesel and naphtha at various levels of dilution and SOI's. The stratification analysis is performed based on the image intensity to determine the stratification levels for diesel and naphtha at various operating conditions.

\section{Methodology}

\section{Fuel Characterization}

Diesel (supplied by Coryton) and naphtha (supplied by Saudi Aramco) are considered for the current study. Naphtha is a less processed fuel in refinery i.e less refining cost and has fuel properties closer to gasoline [19]. The physical and thermal properties of naphtha are compared with diesel and shown in Table 1. When compared to diesel, viscosity of naphtha is lower and this is expected to improve the fuel atomization and air/fuel mixing process. The lower carbon number with decreased boiling point for naphtha than diesel is believed to improve the fuel evaporation and premixing in engines.

Table 1. Fuel Properties of diesel and naphtha

\begin{tabular}{|l|l|l|}
\hline Property & Diesel & Naphtha \\
\hline Density $\left(\mathrm{kg} / \mathrm{m}^{3}\right)$ & 835 & 760 \\
\hline Heat of combustion $(\mathrm{kJ} / \mathrm{kg})$ & 43200 & 44600 \\
\hline Viscosity $\left({ }^{*} 10^{-6} \mathrm{~m}^{2} / \mathrm{s}\right)$ & 2.43 & 0.4 \\
\hline Final boiling point $\left({ }^{\circ} \mathrm{C}\right)$ & 360 & 180 \\
\hline RON & - & 46 \\
\hline H/C ratio & 1.79 & 2.15 \\
\hline Derived cetane number & 54 & 41 \\
\hline
\end{tabular}

The ignition measurements of diesel and naphtha are conducted in an ignition quality tester (IQT) as per ASTM D6890. The specifications of IQT setup and the method involved in estimating ignition delay time (IDT) are detailed in [20] . The experiments are done at IQT standard condition $($ Temperature $=853 \mathrm{~K}$ and Pressure $=21$ bar $)$ at which IDT of n-heptane is $3.8 \mathrm{~ms}$. Figure 1 shows the IQT chamber pressure for diesel and naphtha. The initial chamber pressure for test fuels is lower than the initial pressure due to evaporative cooling. The measured IDT of naphtha is longer $(5.3 \mathrm{~ms})$ and seems to be less reactive than diesel. Though the boiling point of naphtha is lower than diesel, chemical effects predominate the combustion process and thus, IDT is longer for naphtha. Derived cetane number (DCN) of naphtha is 41 , which is lower than diesel $(\mathrm{DCN}=54)$. 


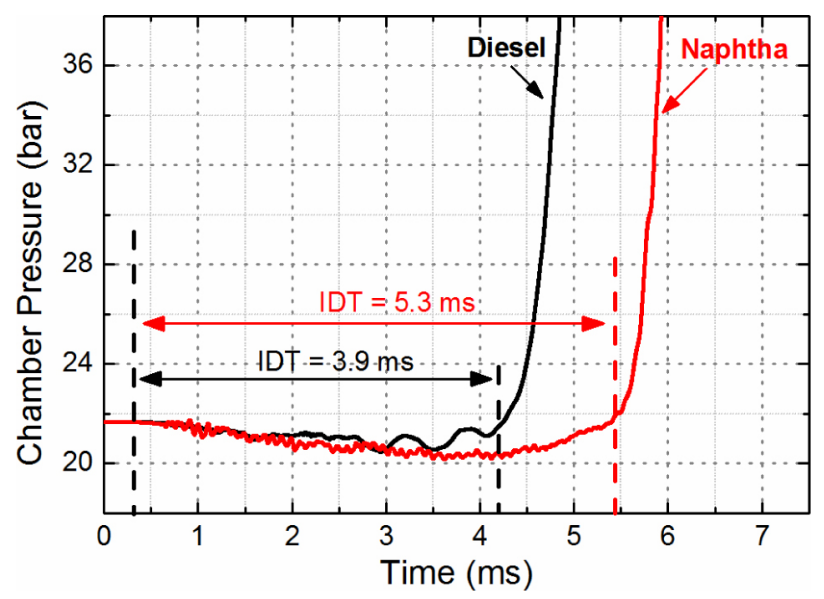

Figure 1. Ignition study of diesel and naphtha in IQT

\section{Experimental Set $U p$}

A single cylinder AVL optical CI engine with a capacity of $511 \mathrm{cc}$ was used for the current experimentation. The detailed specifications of the engine are shown in Table 2. The engine schematic with other accessories is shown in Figure 2. The piston bowl is made of quartz and combustion is visualized from the bottom of the piston. A metal liner surrounds the piston and a pump aids in moving the metal portion below the cylinder head to facilitate cleaning of glass in the piston. A vacuum cleaner creates a negative pressure of $100 \mathrm{mbar}$ in the crankcase that ably prevents oil squirts on the optical components. A jet of air cools the piston from the bottom. The photographic view of the optical piston with a pip in the center of the combustion chamber is shown in Figure 3. Distortions due to the pip in the bowl is shown in the millimeter paper and marked for reference. A high speed video of the combustion process is recorded from the bottom of optical piston by Photron FASTCAM SA4 color camera. For all operating condition, 150 cycles are recorded with the trigger set at $-10 \mathrm{CAD}$ (aTDC) to capture the combustion process. 100 images are recorded for each cycle and the crank angle interval between images is $0.72 \mathrm{CAD}$. The high speed video is captured at the rate of 10,000 frames per second with a pixel resolution of $768 \times 512$ and the aperture for lens is kept at 1.4.

The SOI, fuel injection pressure, mass of fuel injected and valve timing are controlled through engine control unit (ECU) known as AVL FI ${ }^{2 R E}$. A Piezo electric pressure transducer mounted over the cylinder head measures the in-cylinder pressure with a sensitivity of $20 \mathrm{pC} /$ bar. The pressure data were recorded in an interval of $0.2 \mathrm{CAD}$ by AVL indicom software version 2.4. The recorded pressure data was then analyzed using a heat release code and the combustion parameters such as rate of heat release, indicated mean effective pressure (IMEP), CA50 (combustion phasing) and other parameters are determined. The heat release computation entails wall heat model, heat transfer losses, blow by and crevice effects. Initially, rate of heat release is estimated from motored pressure trace and it was deduced to be zero. This gives an indication that the heat release analysis is appropriate; given no heat should be released during motoring condition. Subsequently, rate of heat release is calculated from the pressure traces for fired cases.
Table 2. Specifications of Single cylinder optical CI engine

\begin{tabular}{|c|c|c|}
\hline \multicolumn{2}{|l|}{ Bore } & $85 \mathrm{~mm}$ \\
\hline \multicolumn{2}{|l|}{ Stroke } & $90 \mathrm{~mm}$ \\
\hline \multicolumn{2}{|c|}{ Compression ratio } & $9.5: 1$ \\
\hline \multicolumn{2}{|l|}{ Swept volume } & $511 \mathrm{cc}$ \\
\hline \multicolumn{2}{|l|}{ Engine speed } & $1200 \mathrm{rpm}$ \\
\hline \multicolumn{2}{|c|}{ Fuel injection pressure } & 800 bar \\
\hline \multicolumn{2}{|c|}{ Fuel injection timing } & -10 to $-30 \mathrm{CAD}$ aTDC \\
\hline \multirow{2}{*}{ Intake Valve } & Open & $30 \mathrm{CAD}$ bTDC \\
\hline & Close & $45 \mathrm{CAD}$ aBDC \\
\hline \multirow{2}{*}{ Exhaust Valv } & Open & $50 \mathrm{CAD}$ bBDC \\
\hline & Close & $25 \mathrm{CAD}$ aTDC \\
\hline \multicolumn{2}{|c|}{ Inlet air pressure } & 1.55 to $1.65 \mathrm{bar}$ \\
\hline \multicolumn{2}{|c|}{ Inlet air temperature } & 35 to $160^{\circ} \mathrm{C}$ \\
\hline \multicolumn{2}{|c|}{ Coolant temperature } & $80^{\circ} \mathrm{C}$ \\
\hline \multicolumn{2}{|c|}{ Lubrication oil temperature } & $80^{\circ} \mathrm{C}$ \\
\hline
\end{tabular}

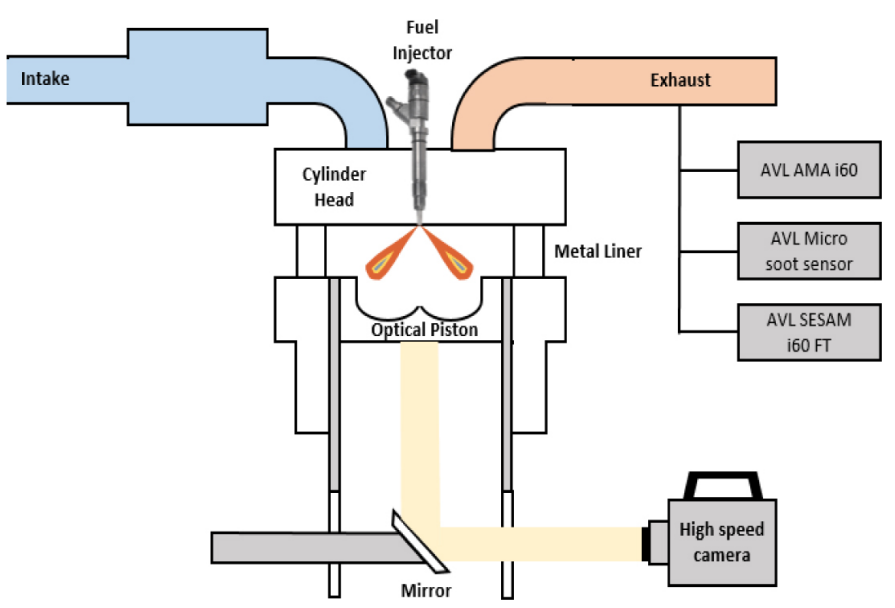

Figure 2. Schematic of optical CI engine

AVL PUMA controls the measurement of torque, intake air and exhaust gas pressure and temperature, coolant and lubricant temperature and engine speed. To facilitate the measurement of all gases in intake, a separate emission channel is incorporated and the emission values are measured using AVL AMA i60 test bench in both intake and exhaust. While $\mathrm{NO}_{\mathrm{X}}$ emission is measured using an FTIR (Fourier transform infra red analyzer) in the range of 0 to $10000 \mathrm{ppm}$, soot concentration is measured using AVL micro soot sensor. 

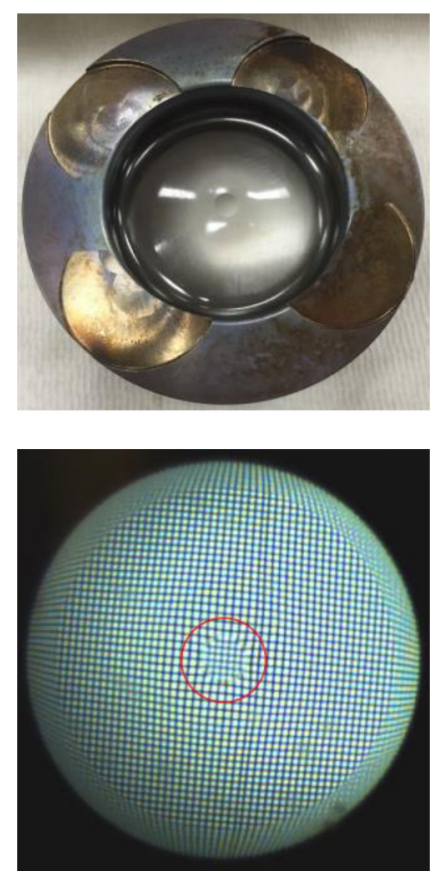

Figure 3. Optical piston (top) and distortions captured in millimeter paper (bottom)

\section{Operating Conditions and Test Procedure}

The engine runs at a speed of $1200 \mathrm{rpm}$ and fuel is injected at a pressure of 800 bar by a common rail fuel injection system. FuelMEP for both diesel and naphtha is calculated as follows,

$$
\text { FuelMEP }=\frac{m_{f} * Q_{L H V}}{V_{d}}
$$

Where, $\mathrm{M}_{\mathrm{f}}-$ Mass of fuel supplied ( $\left.\mathrm{g}\right), \mathrm{Q}_{\mathrm{LHV}}$ - lower heating value $(\mathrm{kJ} / \mathrm{kg})$ and $\mathrm{V}_{\mathrm{d}}$ - displacement volume $\left(\mathrm{m}^{3}\right)$. For the reported calorific value of diesel and naphtha (Table 1), mass of fuel injected is varied to maintain a constant fuelMEP of 5.1 bar. Since IMEP is lower (low load condition), the quantity of fuel injected per cycle is lower. The $\mathrm{SOI}$ is swept from $-10 \mathrm{CAD}$ (aTDC) to - $30 \mathrm{CAD}$ (aTDC) i.e., from $\mathrm{CI}$ to PPC condition. The intake air pressure is boosted (1.55 bar to 1.65 bar absolute pressure) and the motored pressure at TDC is kept at 35 bar. In the current study, oxygen $\left(\mathrm{O}_{2}\right)$ concentration in the intake is displaced by nitrogen $\left(\mathrm{N}_{2}\right)$ through a mass flow meter to have various levels of dilution at $20.7 \%, 17.7 \%$ and $14.7 \%$. The intake air is heated using an inline heater (from $35^{\circ} \mathrm{C}$ to $160^{\circ} \mathrm{C}$ ) to facilitate control of combustion during PPC. Since the lubrication quality is low for naphtha, 500ppm of lubricating additive from infenium was added to prevent the failure of fuel pump.

\section{Image Processing and Stratification Analysis}

The recorded high speed video is converted into images and each cycle with 100 images is analyzed separately. The natural luminosity of the images are inferred and the color camera that was used showed blue and yellow images. It is interesting to analyze the color images of combustion and investigate the stratification levels. The stratification analysis is based on the methodology from $\mathrm{Tu} / \mathrm{e}$ Eindhoven University of Technology [12]. The images are examined in a cylindrical coordinate system and the 7 clouds of combustion, representative of 7-hole nozzle spray, are considered. Stratification analysis was limited by optical distortions in the piston bowl and thus, only angular stratification was analyzed. The angular stratification is determined by selecting a band in radial direction of cylindrical coordinate system. The intensity of images is averaged in the radial direction with respect to polar angle $(\theta)$ [12]. The difference between maximum and minimum angular signal is normalized by the sum of intensities to explore the stratification levels between 0 and 1 at various operating conditions.

The estimation of angular stratification is based on the below formulation,

$$
S t r_{\theta}=\frac{1}{n} \sum_{i=1}^{n} \frac{\left(I_{\max }-I_{\min }\right)_{i}}{\left(I_{\max }+I_{\min }\right)_{i}}
$$

Where $\operatorname{Str}_{\theta}=$ Angular stratification, $\mathrm{n}$ - number of injection holes, $\mathrm{I}_{\max }$ - Maximum angular intensity in $\mathrm{i}^{\text {th }}$ combustion cloud, $\mathrm{I}_{\min }$ - Minimum angular intensity in $\mathrm{i}^{\text {th }}$ combustion cloud and $\theta$ - Polar angle. More detailed information on stratification analysis can be found in the previously published papers $[\underline{9}, \underline{12}]$. For the stratification analysis, 30 cycles is considered. In total, the images for 150 cycles are recorded and separated into 5 cases, each case with 30 cycles. The level of stratification for each set is same. In the present study, a full optical piston is not used and combustion at advanced SOI could not be captured properly with the glass piston bowl. Combustion visualization is not proper at SOI before $-20 \mathrm{CAD}$ (aTDC) as full view of combustion chamber is not obtained. Because of this limitation, stratification analysis at early SOI is not appropriate.

\section{Results and Discussion}

\section{Combustion Phasing}

Combustion phasing (crank angle at which $50 \%$ of fuel is burnt CA50) for diesel at $\mathrm{T}=35^{\circ} \mathrm{C}$ and $\mathrm{O}_{2}=20.7 \%$ is plotted against SOI (figure 4). From the plot, it is clear to note the transition from CI to PPC when the SOI is swept from late to early injections. For late injections ( $-10 \mathrm{CAD}$ aTDC), there is a link between combustion phasing and SOI, and this is regarded as CI combustion. At around SOI of -20 CAD (aTDC), PPC is inferred for diesel. At advanced injections, the combustion phasing starts to decouple from SOI. The trend in CA50 decreases from CI and then takes a hook, before starting to decouple from SOI. These findings are in consonance with the past reports wherein the same effect of SOI on combustion phasing is elucidated $[\underline{21}, \underline{22}]$. When SOI is advanced, the mixing time for air and fuel is increased and the mixture become more homogenous. As premixing is improved due to fuel evaporation, the local equivalence ratio decreases (lean burning) and this prolongs the ignition delay: the start of combustion (CA05) plot with respect to SOI confirms this, as shown in figure 5.

When naphtha is tested in optical CI engine, air/fuel mixture doesn't ignite at an intake air temperature of $35^{\circ} \mathrm{C}$ due to its lower reactivity. However, when the intake air temperature is increased, auto ignition of naphtha is supported and stable combustion is attained. At an 
intake air temperature of $90^{\circ} \mathrm{C}, \mathrm{CA} 50$ for naphtha is closer to diesel and so does is the SOC (figure 4 and 5 ). The trend of CA50 for naphtha is comparable to diesel, while only the intake air temperature is different. For high octane fuels, SOI is advanced for achieving same CA50 as that of standard fuel [23]. Here, from -10 CAD (aTDC) to -17 CAD (aTDC), CA50 of naphtha is comparable to diesel. Before -17 CAD (aTDC), CA50 is lower for naphtha than diesel due to the combined effect of early SOI and increased intake air temperature.

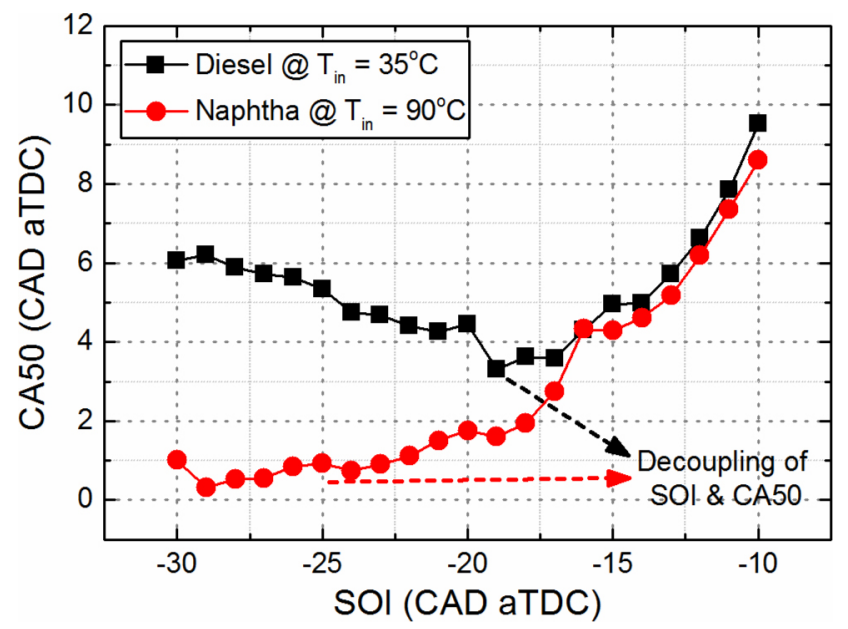

Figure 4. CA50 plot for diesel and naphtha with respect to SOI

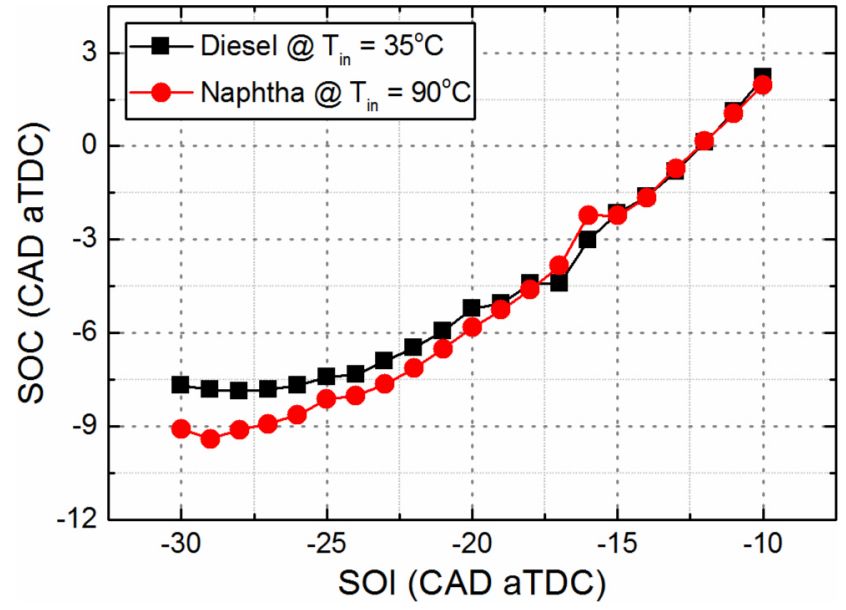

Figure 5. SOC plot for diesel and naphtha with respect to SOI

\section{Effect of Dilution on Combustion Phasing}

In an attempt to improve premixing and homogeneity of air/fuel mixture, intake air is diluted by $\mathrm{N}_{2}$. The effect of dilution on combustion phasing is studied for naphtha (figure 6). When $\mathrm{O}_{2}$ in the intake is reduced from $20.7 \%$ to $17.7 \%$, combustion phasing is retarded. Dilution by $\mathrm{N}_{2}$ reduces the reactivity of the mixture and this prolongs the combustion process with increased ignition delay. The intake air temperature is increased from $90^{\circ} \mathrm{C}$ to $105^{\circ} \mathrm{C}$ to improve the combustion process and combustion phasing was advanced. CA50 for naphtha at $\mathrm{T}_{\text {in }}=105^{\circ} \mathrm{C}$ and $\mathrm{O}_{2}=17.7 \%$ is comparable to CA50 for naphtha at $\mathrm{T}_{\text {in }}=90^{\circ} \mathrm{C}$ and $\mathrm{O}_{2}=20.7 \%$, showing that combustion phasing is recovered with the increase in intake air temperature. When $\mathrm{O}_{2}$ in the intake is reduced to $14.7 \%$, combustion is further retarded and to compensate this, intake air temperature is increased to $160^{\circ} \mathrm{C}$. At this condition, CA50 for naphtha is matched with the baseline CA50. Thus, dilution is effected to improve the combustion homogeneity and intake air temperature is increased to match the combustion phasing for naphtha.

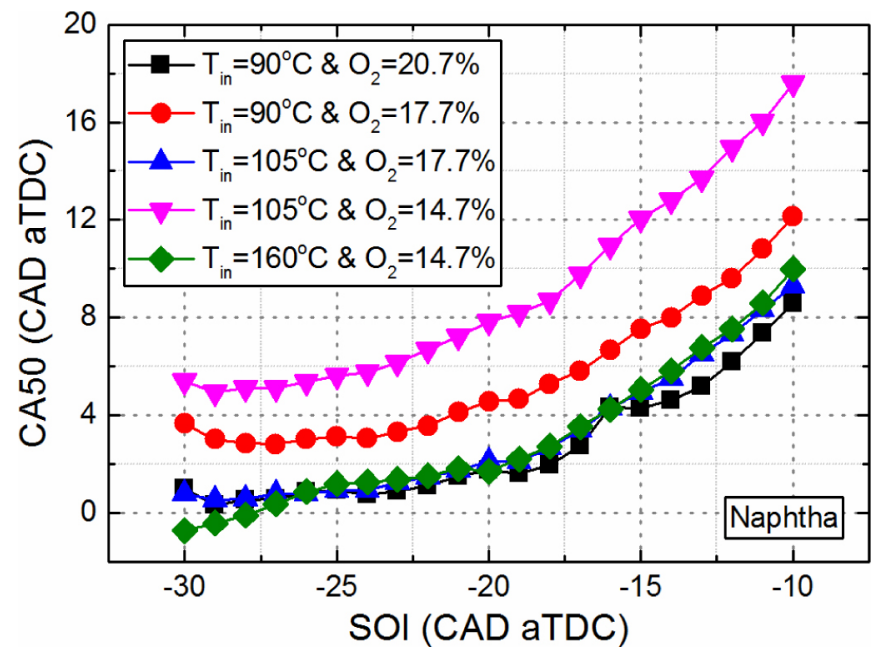

Figure 6. Combustion phasing for naphtha with respect to SOI at various levels of dilution and intake air temperature

\section{In-Cylinder Pressure and Rate of Heat Release}

The in-cylinder pressure and rate of heat release are compared for naphtha and diesel at SOI $=-10 \mathrm{CAD}$ (aTDC), $-15 \mathrm{CAD}$ (aTDC) and $-20 \mathrm{CAD}(\mathrm{aTDC})$ and shown in figure 7. Peak in-cylinder pressure for naphtha is comparable to diesel; however the intake air temperature is increased to $90^{\circ} \mathrm{C}$ for matching diesel combustion. For the same fuelMEP, diesel and naphtha produces an IMEP of 2.55 and 2.46 bar, respectively, when SOI is $-10 \mathrm{CAD}$ (aTDC). For both diesel and naphtha, IMEP is higher for SOI in the range -10 CAD (aTDC) to -20 CAD (aTDC) and it starts to decrease when SOI is advanced further.

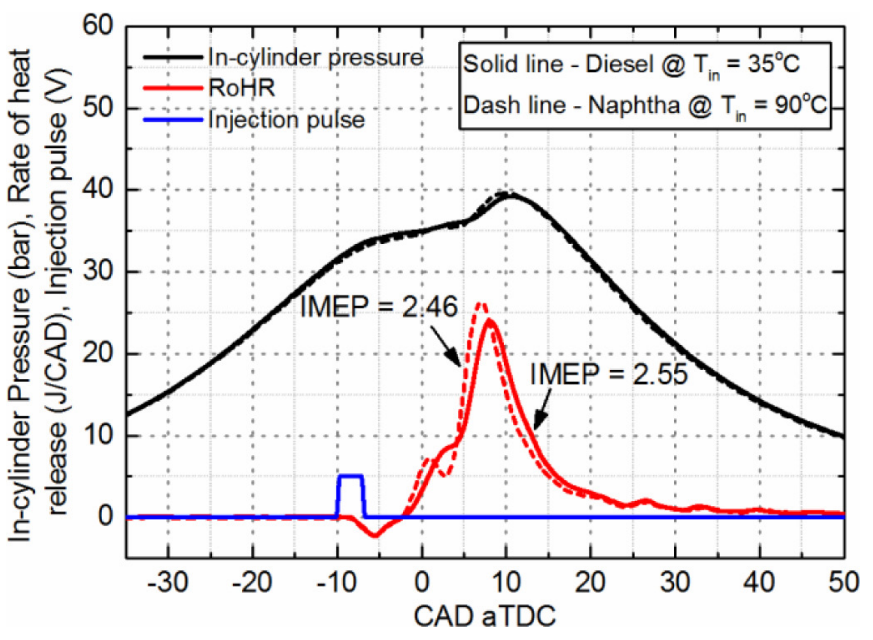

a.

Figure 7. In-cylinder pressure and rate of heat release for diesel and naphtha at a) $\mathrm{SOI}=-10 \mathrm{CAD}(\mathrm{aTDC}), \mathrm{b}) \mathrm{SOI}=-15 \mathrm{CAD}(\mathrm{aTDC})$, c) $\mathrm{SOI}=-20 \mathrm{CAD}$ (aTDC) with inlet $\mathrm{O}_{2}$ concentration of $20.7 \%$. 


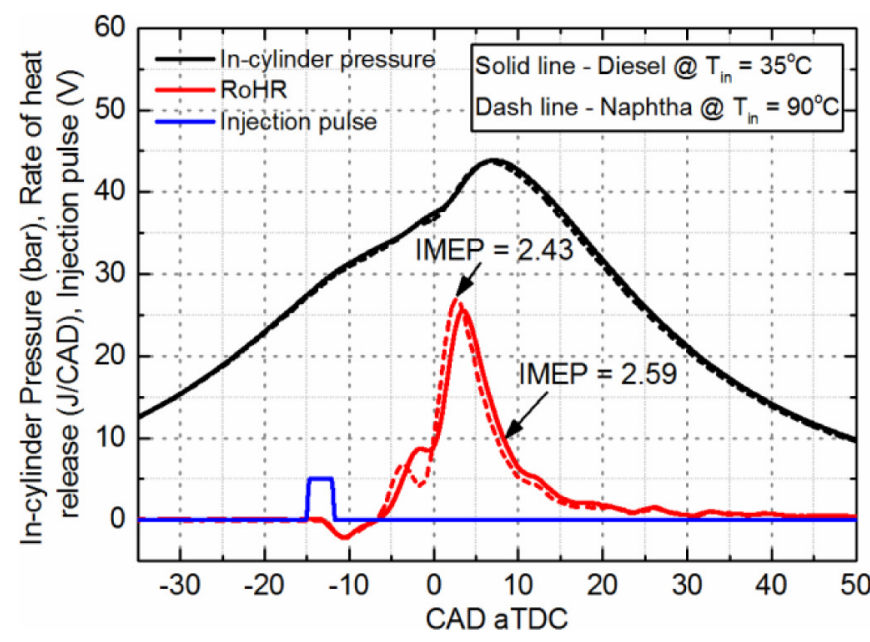

b.

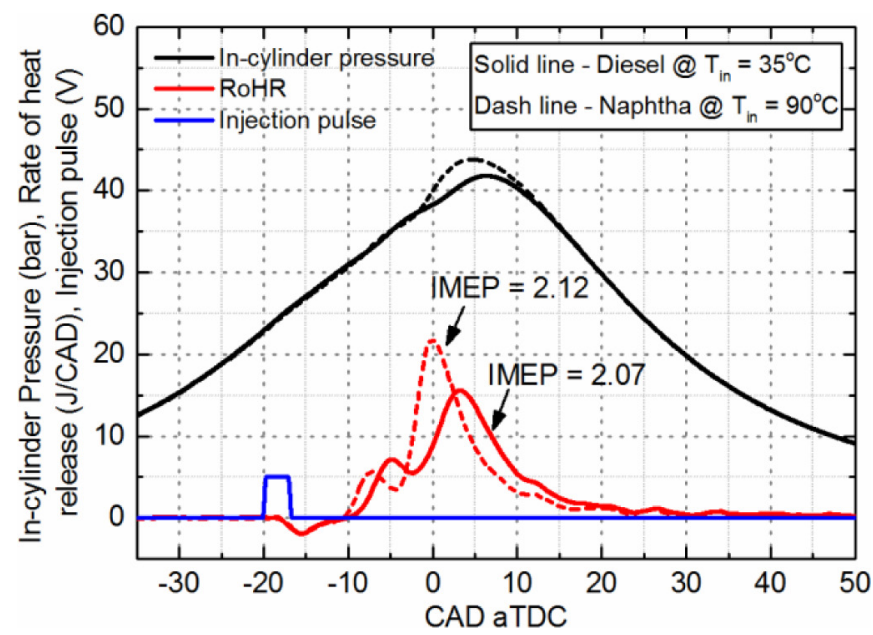

c.

Figure 7. (cont.) In-cylinder pressure and rate of heat release for diesel and naphtha at a) $\mathrm{SOI}=-10 \mathrm{CAD}(\mathrm{TDC}), \mathrm{b}) \mathrm{SOI}=-15 \mathrm{CAD}(\mathrm{TDC}), \mathrm{c}) \mathrm{SOI}=$ $-20 \mathrm{CAD}(\mathrm{aTDC})$ with inlet $\mathrm{O}_{2}$ concentration of $20.7 \%$.

When comparing the rate of heat release for diesel and naphtha, it is noticed that peak heat release rate is slightly higher for naphtha. The rate of heat release rises sharply for naphtha, while it increases gradually for diesel. Since the properties and reactivity of naphtha are different from diesel, intake air temperature is raised to $90^{\circ} \mathrm{C}$. The increased temperature in the intake attributes to slightly higher heat release rate for naphtha than diesel. Interestingly, there is an initial bump in the rate of heat release curve for diesel and naphtha and this is cool flame region. Low temperature reaction phase depends mainly on chemical properties (fuel composition and fuel structure) and in-cylinder conditions (in-cylinder temperature and pressure) [24].

The rate of heat release at different SOI for naphtha at $\mathrm{T}_{\text {in }}=90^{\circ} \mathrm{C}$ and $\mathrm{O}_{2}=20.7 \%$ and diesel at $\mathrm{T}_{\text {in }}=35^{\circ} \mathrm{C}$ and $\mathrm{O}_{2}=20.7 \%$ is shown in figure 8. At this condition, combustion phasing of naphtha is comparable to diesel and it is rational to compare the in-cylinder pressure and heat release rate. For late SOI (-10 CAD aTDC), combustion occurs late after TDC for diesel. Both diesel and naphtha shows a lump in heat release rate and this is an evidence of low temperature combustion as explained above. At early injection, the peak heat release rate of diesel is much lower. The mass of fuel injected is less and the fact that more time is available for premixing at early SOI makes the mixture lean, which affect the combustion. Naphtha shows a pronounced premixed combustion until -25 CAD (aTDC) and the peak heat release rate decreases after that. While diffusion combustion phase is evident for diesel and naphtha at late SOI, it turns predominantly premixed when $\mathrm{SOI}$ is advanced. The plot of rate of heat release for naphtha at various intake $\mathrm{O}_{2}$ concentrations and temperature for $\mathrm{SOI}=-10 \mathrm{CAD}(\mathrm{aTDC})$ is shown in figure 9. As $\mathrm{O}_{2}$ concentration in the intake is decreased to $17.7 \%$ from $20.7 \%$, ignition delay is prolonged, and the peak heat release rate is decreased. Reduction in intake $\mathrm{O}_{2}$ concentration has a reflection on in-cylinder temperature and mixture homogeneity [25] If combustion phasing is advanced, diffusion controlled combustion shifts towards modulated kinetic controlled combustion [26]. To attain stable combustion with dilution, intake temperature is increased to $105^{\circ} \mathrm{C}$ and rate of heat release is comparable with naphtha at $\mathrm{T}_{\text {in }}=$ $90^{\circ} \mathrm{C}$ and $\mathrm{O}_{2}=20.7 \%$. Similarly, when $\mathrm{O}_{2}$ concentration is $14.7 \%$, the intake temperature is increased to $160^{\circ} \mathrm{C}$ to match the combustion phasing for base line naphtha.

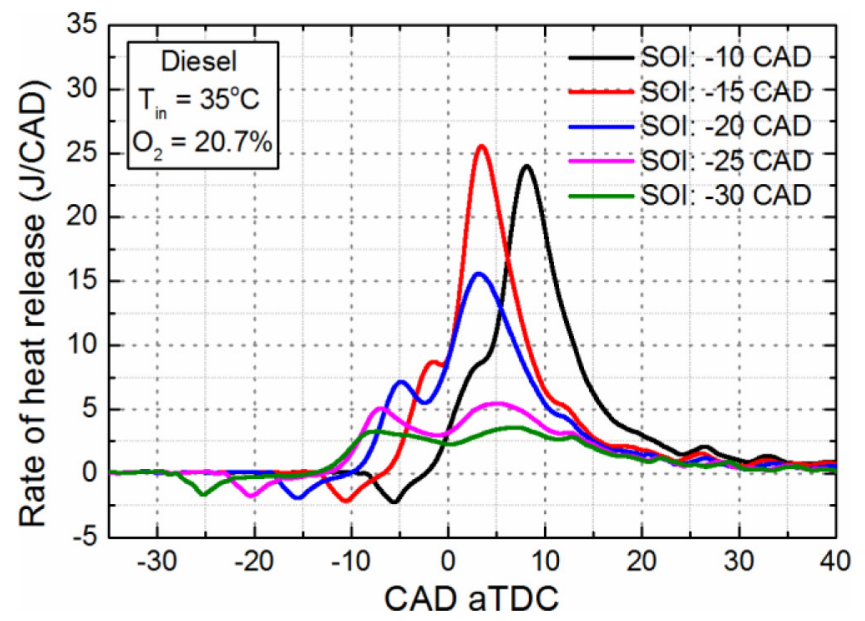

a.

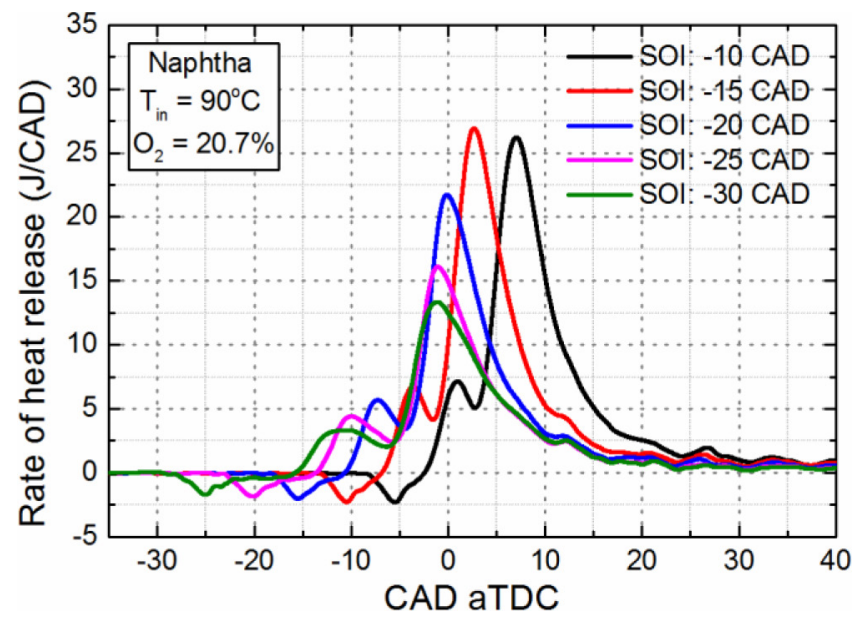

b.

Figure 8. Rate of heat release for diesel and naphtha at various SOI 


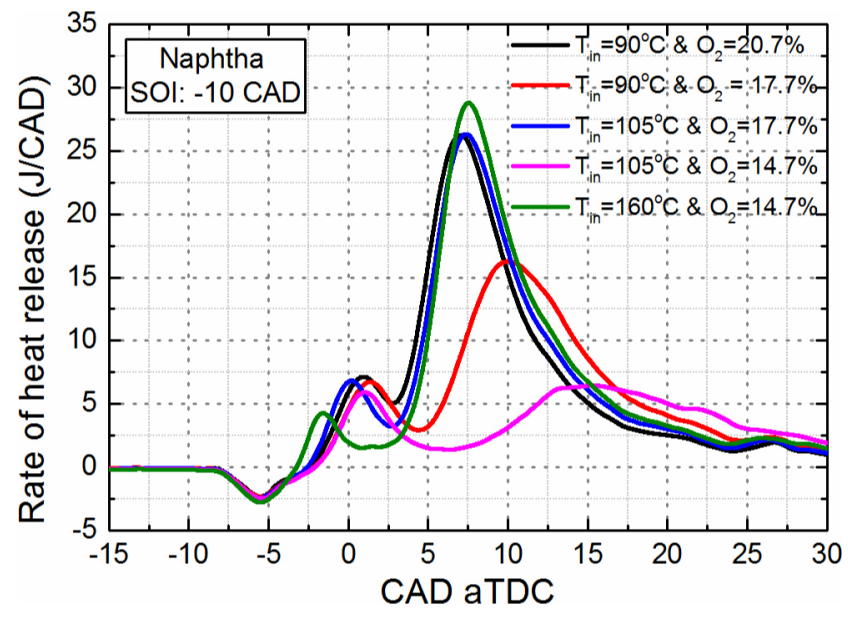

Figure 9. Rate of heat release for naphtha at various levels of dilution and intake temperature at $\mathrm{SOI}=-10 \mathrm{CAD}$ aTDC

\section{Combustion Visualization}

The in-cylinder pressure and rate of heat release are correlated with the high-speed images and better understanding of the combustion process is obtained (figure 10). The color of the flame changes from blue to yellow during combustion. Blue color signifies the initial low temperature combustion before the diffusion dominant phase of combustion. The dark yellow spots at latter stages of combustion are due to injector dribbling. Combustion clouds representing sprays are evident in the images and soot flames are visible after 13 CAD aTDC when SOI is -10 CAD aTDC.

The difference between combustion phasing is quite obvious from this study based on the color and intensity of high speed images. The first image of combustion is observed at 7.2 CAD (aTDC) for SOI = -10 CAD (aTDC) and intensity of image as well as the flame area increases as the flame starts to propagate towards the outer ring of combustion chamber. While CA10 occurred at 3.7 CAD (aTDC) and maximum intense image is seen at 11 CAD (aTDC). The percentage of heat released at respective crank angle degrees is shown with the images at the top. Moving from left, the percentage of heat released increases and mixing controlled combustion is certain for diesel. All these images are shown at low load condition when IMEP is in the range of 2 to 2.5 bar. Diesel PPC is studied at low load, given the ignition delay is short and enables only low stratified mixture before ignition [27].

The images of combustion for naphtha at $\mathrm{SOI}=-10 \mathrm{CAD}$ (aTDC) are shown in figure 11, synchronized with in-cylinder pressure and heat release data. When compared to diesel, the percentage of heat released is slightly higher for naphtha. It is worth reiterating that the intake temperature is increased for naphtha to match the combustion phasing of diesel. At this condition, the combustion images of naphtha, compared with diesel at same SOI, elucidate that combustion is similar to diesel. Combustion is stratified for naphtha as SOI is swept from early to late injection. This is in parallel with the results of the previous study for PRF 70 wherein combustion is more stratified for late injections than advanced injections [12]. As
SOI is advanced to -20 CAD aTDC, the diffusion flames become less evident for diesel and naphtha (figure 12). For early injection, combustion is predominantly premixed and diffusion combustion is more pronounced for late injections.

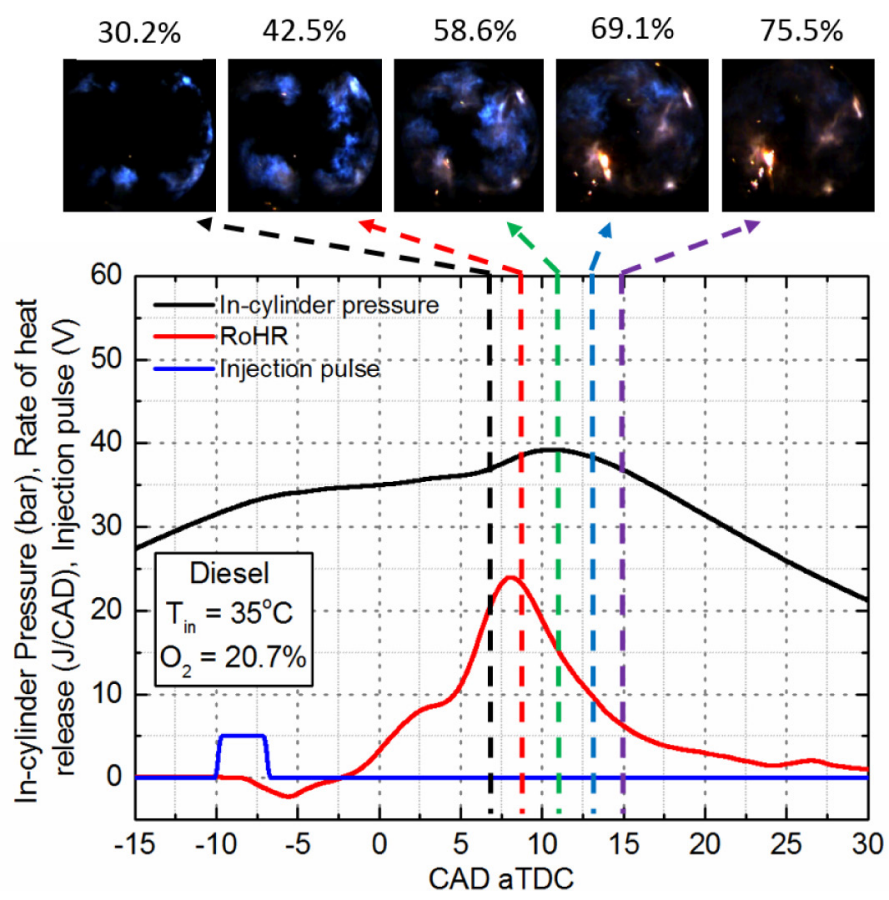

Figure 10. In-cylinder pressure and rate of heat release for diesel at SOI $=-10$ CAD. Top: high speed images of combustion at various crank angle with respective percentage of heat released.
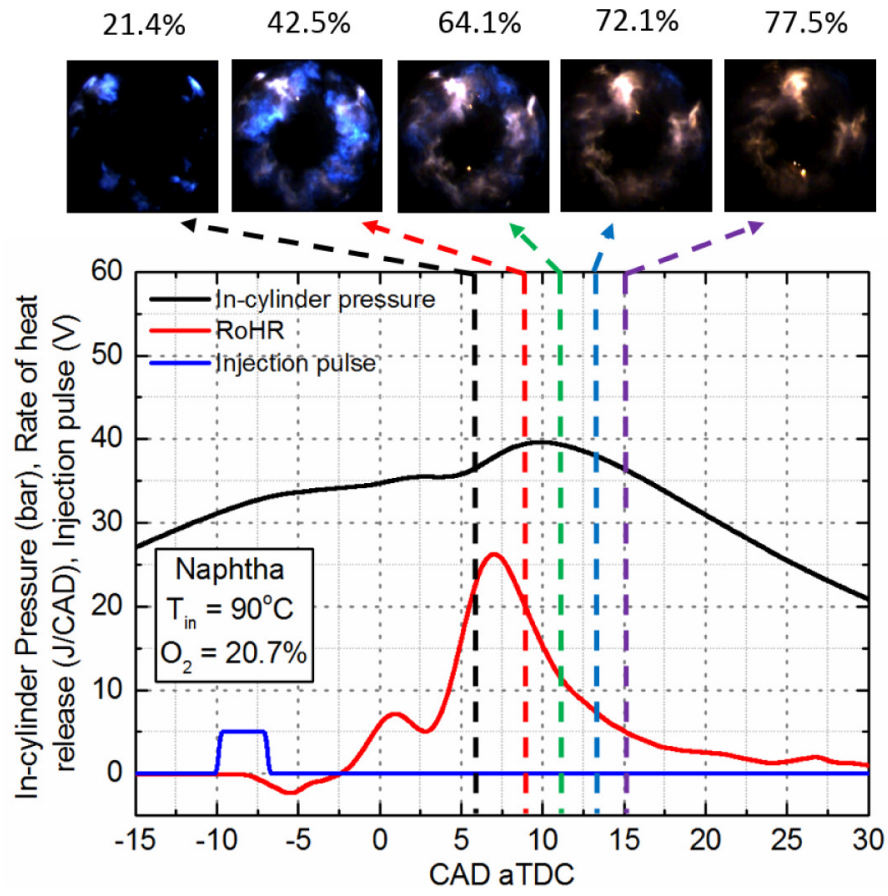

Figure 11. In-cylinder pressure and rate of heat release for naphtha at SOI = -10 CAD. Top: high speed images of combustion at various crank angle with respective percentage of heat released. 


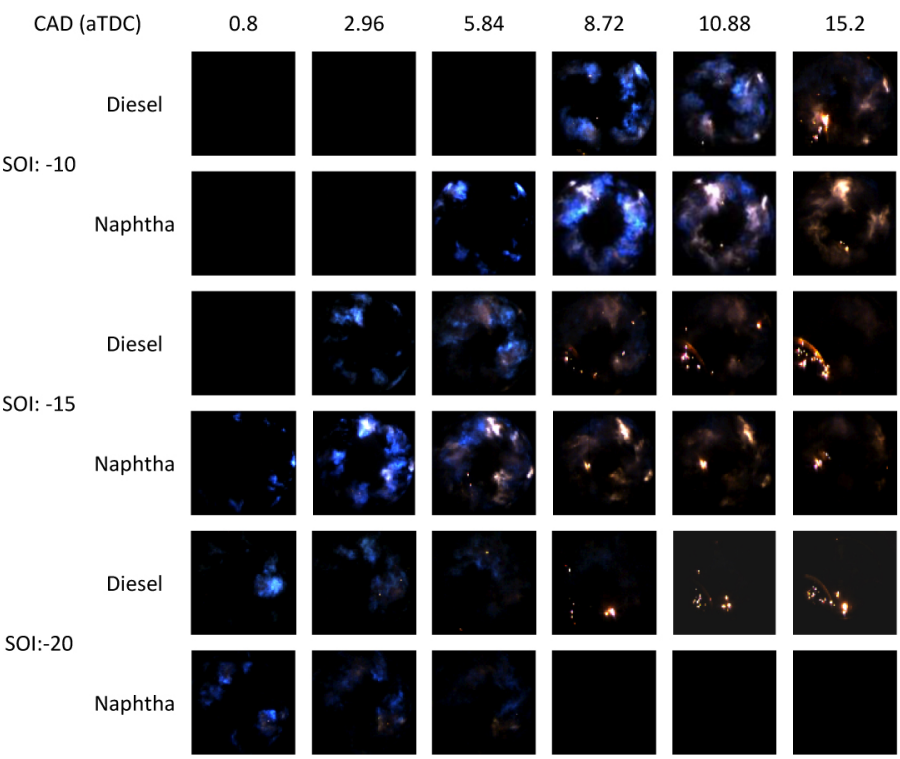

Figure 12. Images of combustion for diesel and naphtha compared at various SOI with intake $\mathrm{O}_{2}$ concentration of $20.7 \%$

The decrease in luminosity is noticed when SOI is swept from late to early SOI. The luminosity of combustion is low when there is no diffusion combustion and soot formation [ $[$ ]. However, when SOI = $-10 \mathrm{CAD}$ (aTDC), intensity of the both blue and yellow flames is higher when compared to the intensity of image at SOI of $-15 \mathrm{CAD}$ (aTDC) and -20 CAD (aTDC). The combustion image at various levels of dilution is shown in Figure 13. With dilution premixing is increased (decreased luminosity) and when intake air temperature is increased, the luminosity of images is higher.

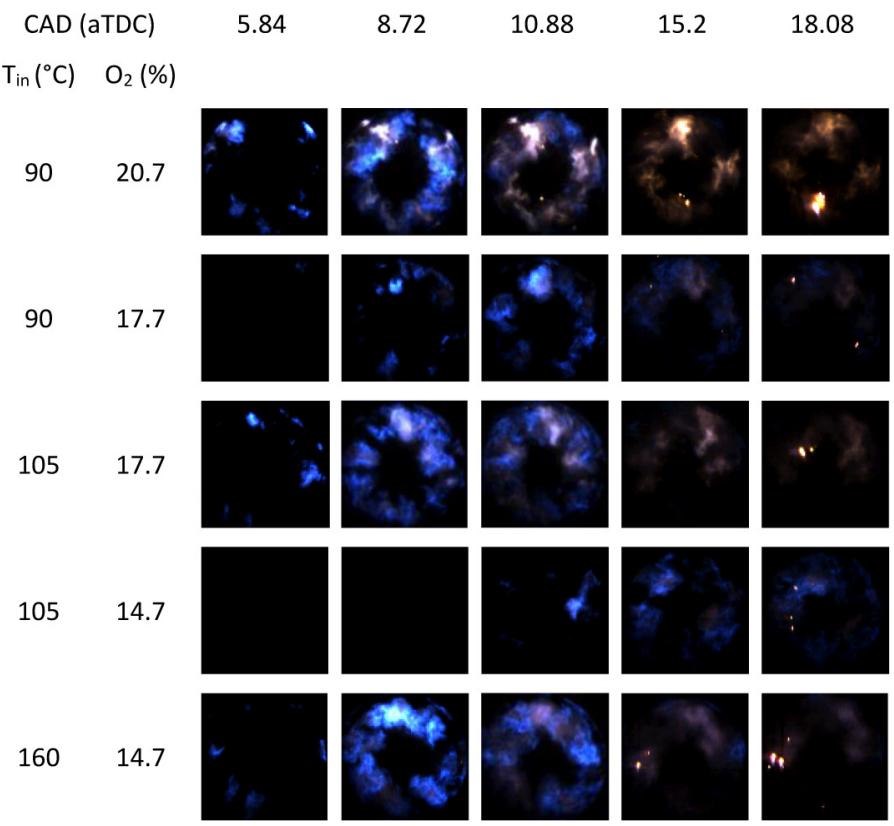

Figure 13. Images of combustion for naphtha with various dilution level and intake air temperature at SOI of $-10 \mathrm{CAD}$ aTDC

\section{Combustion Stratification}

The effect of advancement in fuel injection timing, intake air dilution and increase in intake air temperature on combustion stratification is studied for diesel and naphtha. The angular stratification for diesel and naphtha at an intake temperature of $35^{\circ} \mathrm{C}$ and $90^{\circ} \mathrm{C}$, respectively, is shown in figure 14 at various SOI. When fuel is injected early into the compressed air, temperature is high enough to evaporate the fuel and time is also sufficient to make the mixture homogeneous.

However, for late injections, fuel impinges on the piston bowl, which has a lower surface temperature when compared to the temperature of the compressed air. The evaporation of the fuel is affected and this together with the reduced time available for air/fuel mixing increases the stratification. For late SOI, stratification level is higher for both diesel and naphtha as there is less time available for premixing. However, when SOI is advanced, stratification level is decreased. For early SOI of -30 CAD (aTDC), level of stratification for both diesel and naphtha is 0.1 . It is useful to link the level of stratification with flame intensity and analyze the relation between them. The plot of mean intensity as a function of SOI for diesel and naphtha (figure 15) show the same trend as the maximum stratification. The maximum stratification depends on the luminosity of images and when mean intensity decreases, stratification level decreases.
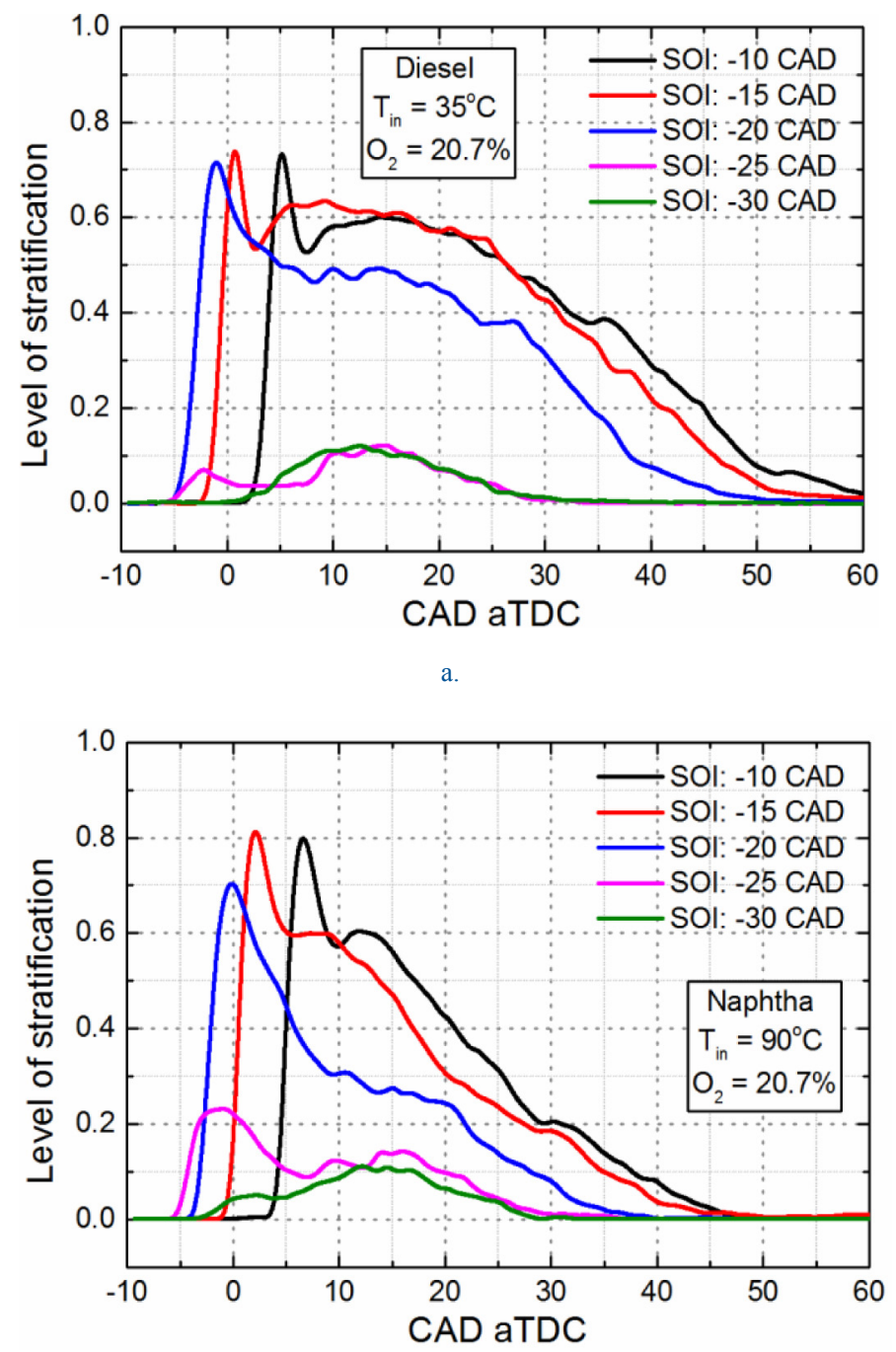

b.

Figure 14. Level of stratification for diesel and naphtha at various SOI

To examine the level of stratification for naphtha and diesel more clearly, maximum value of angular stratification is plotted with respect to SOI and shown in Figure 15. This plot shows that the maximum stratification for naphtha and diesel are comparable. For 
both the fuels, maximum stratification decreased from 0.8 to 0.1 as $\mathrm{SOI}$ is advanced from $-10 \mathrm{CAD}$ (aTDC) to $-30 \mathrm{CAD}$ (aTDC). Since intake air temperature is increased to compensate for the lower reactivity of naphtha, combustion is matched with diesel and the degree of stratification is also similar. Thus, naphtha behaves similar to diesel despite its distinct fuel properties at various SOI, signifying that the shift in combustion homogeneity from CI to PPC is similar for both these fuels.

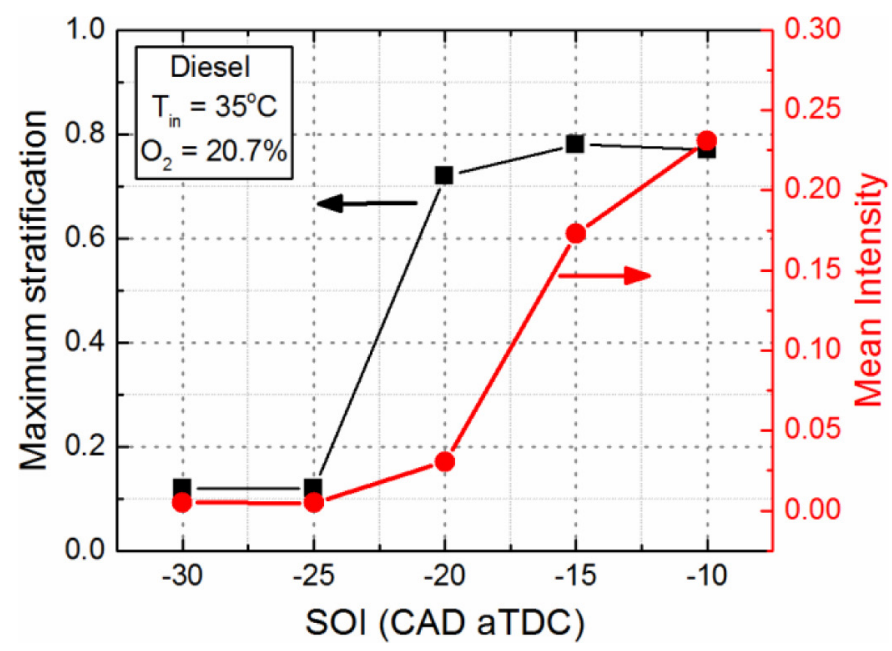

a.

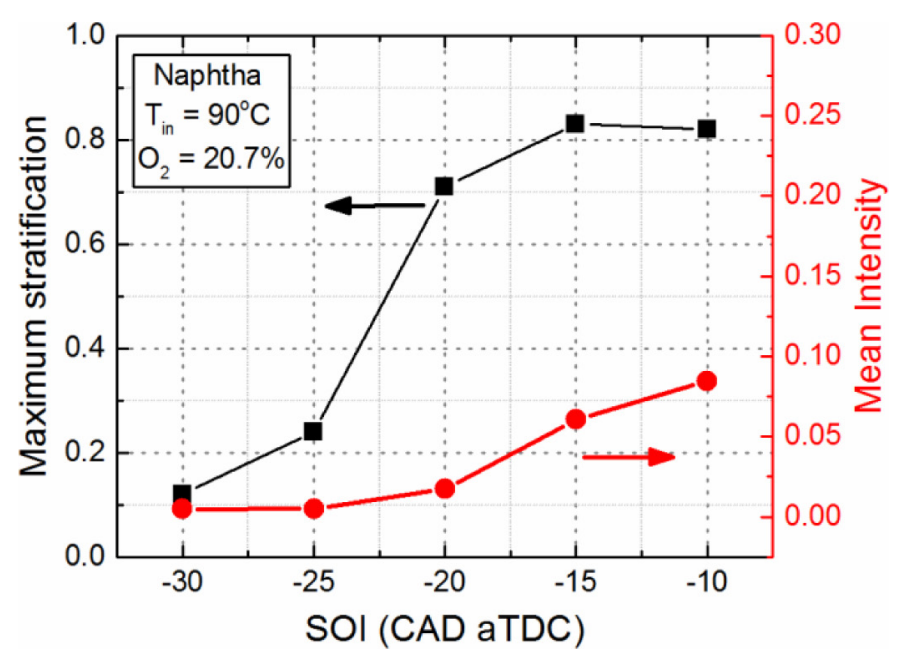

b.

Figure 15. Maximum stratification and mean intensity with respect to SOI for diesel and naphtha

The effect of dilution on angular stratification is studied for naphtha at $\mathrm{SOI}=-10 \mathrm{CAD}(\mathrm{aTDC})$, shown in Figure 16. The decrease in $\mathrm{O}_{2}$ concentration from $20.7 \%$ to $17.7 \%$ improves air/fuel mixing. Dilution turns the mixture leaner and increases the ignition delay, which actually prolongs the combustion to improve premixing. The level of stratification further decreased drastically by 0.5 when $\mathrm{O}_{2}$ in the intake is reduced to $14.7 \%$. However, increased intake air temperature improves the combustion and stratification level is increased. The objective to move towards PPC from CI combustion mode is met by increasing the dilution level in the intake. Increase in intake air temperature helps to attain stable combustion and thereby, combustion becomes stratified.

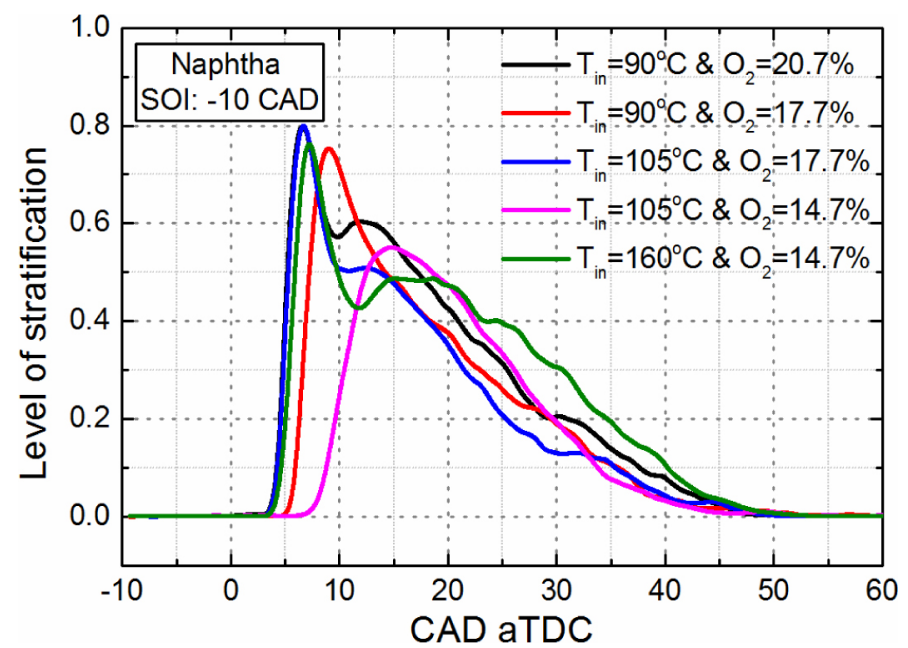

Figure 16. Effect of dilution and intake air temperature on level of stratification for naphtha

\section{NO ${ }_{X}$ and Soot Emission}

In the previous studies in optical CI engine that investigates combustion stratification, emission results are rarely reported. To make the analysis comprehensive, we have coupled $\mathrm{NO}_{\mathrm{X}}$ and soot emission with the high speed images of combustion from optical engine and some inferences are drawn. $\mathrm{NO}_{\mathrm{X}}$ and soot emission for diesel at $\mathrm{T}_{\text {in }}=35^{\circ} \mathrm{C}$ and $\mathrm{O}_{2}=20.7 \%$ and naphtha at $\mathrm{T}_{\text {in }}=90^{\circ} \mathrm{C}$ and $\mathrm{O}_{2}$ $=20.7 \%$ are shown in Figure 17. From the results, it is certain to note that $\mathrm{NO}_{\mathrm{X}}$ and soot emission in general are lower in a CI engine for both diesel and naphtha, which could be due to the operation of engine at low load (IMEP in the range 2 to 2.5 bar). $\mathrm{NO}_{\mathrm{X}}$ emission is higher for both diesel and naphtha at late injections in the range -10 CAD aTDC to $-15 \mathrm{CAD}$ aTDC i.e. during CI combustion. However, when moving from $\mathrm{CI}$ to $\mathrm{PPC}$ condition, $\mathrm{NO}_{\mathrm{X}}$ emission decreases and attains a lower value. This is attributed to increased premixing when SOI is advanced that lowers the local equivalence ratio (lean burning) to decrease $\mathrm{NO}_{\mathrm{X}}$ emission. While diesel attains a constant lower value of $\mathrm{NO}_{\mathrm{X}}$ emission at $-20 \mathrm{CAD}$ (aTDC), it happens late for naphtha after -25 CAD (aTDC). With early SOI, combustion becomes too lean due to premixing to the extent that it extinguishes combustion and increases the soot emission for diesel.

The observed trend in $\mathrm{NO}_{\mathrm{X}}$ and soot emissions can be understood by correlating with high speed combustion images, shown in figure 12. While combustion images with high luminosity at late injection correspond to increased $\mathrm{NO}_{X}$ emission and lower soot concentration, images with low luminosity are related to decreased $\mathrm{NO}_{\mathrm{X}}$ emission and increased soot emission. $\mathrm{NO}_{\mathrm{X}}$ emission for naphtha is slightly higher than diesel, given that the peak in-cylinder temperature is expected to be higher for naphtha. For naphtha, intake air temperature is increased to $90^{\circ} \mathrm{C}$ to match the CA50 with diesel. Thus, it is certain that the temperature is high enough for naphtha in the intake and this increases $\mathrm{NO}_{\mathrm{X}}$ formation. Furthermore, the increased in-cylinder temperature also promotes soot oxidation to decrease soot concentration. The decreased soot concentration for naphtha could also be attributed to lower aromatics present in it compared to diesel. It is noteworthy to point out that the total aromatics content in naphtha is $11.2 \%(\mathrm{v} / \mathrm{v})$, while for diesel it is $28.7 \%(\mathrm{v} / \mathrm{v})$. While aromatics are precursors to soot formation during combustion process $[\underline{28}, \underline{29}, \underline{30}]$, the amount of olefins present in naphtha is also lower $(1.8 \% \mathrm{v} / \mathrm{v})$, which reduces the soot concentration. 


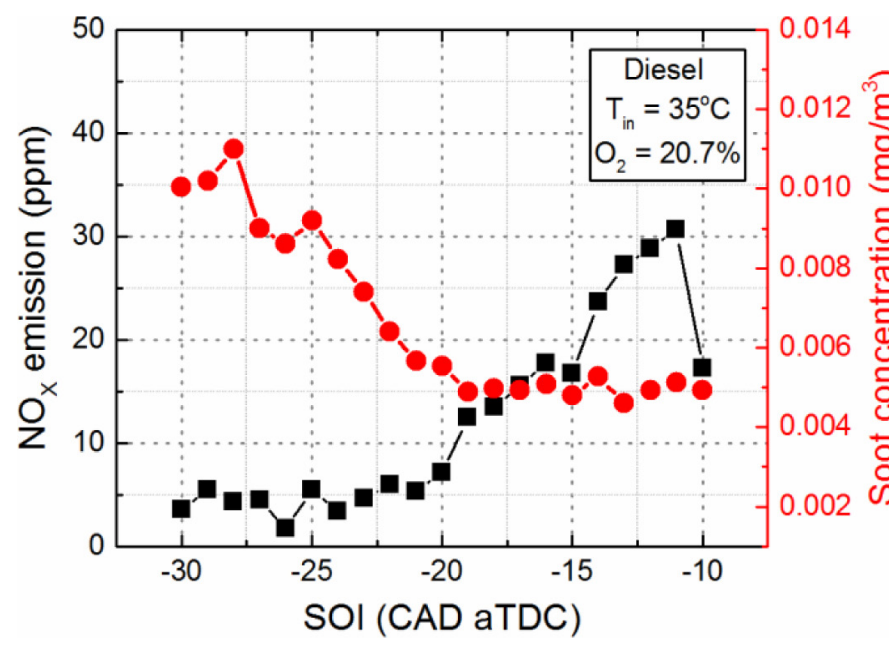

a.

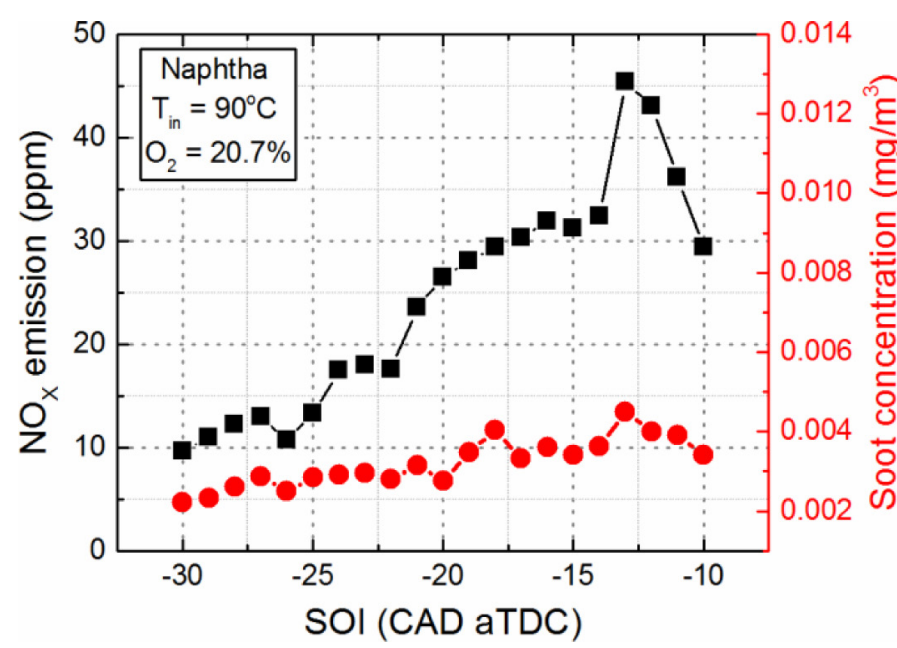

b.

Figure 17. $\mathrm{NO}_{\mathrm{X}}$ emission and Soot concentration for diesel and naphtha

\section{Conclusions}

Combustion stratification is studied for naphtha in an optical CI engine and the results are compared with diesel. When SOI is swept from late to early injection, combustion is drifted from CI to PPC for both naphtha and diesel. Combustion phasing of naphtha is made comparable to diesel by increasing the intake air temperature from $35^{\circ} \mathrm{C}$ to $90^{\circ} \mathrm{C}$. The shift towards PPC condition occurs at SOI of -20 CAD (aTDC) and -25 CAD (aTDC) for diesel and naphtha, while a better CI combustion is attained at -10 CAD (aTDC). The in-cylinder pressure and rate of heat release are synchronized with the high speed images of combustion for diesel and naphtha when SOI $=-10 \mathrm{CAD}$ (aTDC). Diesel and naphtha shows cool flame region due to low temperature reaction phase. When SOI is advanced, premixing is improved for both these fuels and intensity of combustion images diminishes. The peak heat release rate is slightly higher for naphtha; while IMEP for diesel and naphtha are comparable.

In an attempt to study the combustion stratification, the $\mathrm{O}_{2}$ concentration in intake is reduced to $17.7 \%$ and $14.7 \%$. With the increase in dilution, combustion phasing is advanced. With dilution the intensity of images decreases due to increased premixing. For $\mathrm{O}_{2}$ concentration of $17.7 \%$ and $14.7 \%$, intake air temperature is increased and combustion phasing is brought closer to the baseline combustion phasing. For this, the natural luminosity of the combustion images is increased and the combustion clouds are clearly visible. The level of stratification is determined based on the intensity of images in cylindrical coordinate system. The angular stratification for naphtha and diesel at various SOI is comparable. For early injections, the level of stratification is lower and higher for late injection. Thus, when SOI is swept from advanced to late injection timing, combustion is shifted from PPC to CI. When the intake air is diluted with $\mathrm{N}_{2}$, premixing is further improved and increasing the intake temperature improves the combustion stratification. This study summarizes that for late injections, combustion phasing is directly linked with SOI, while it starts to decouple when SOI is advanced. Besides SOI, intake oxygen concentration and temperature plays a prominent role in improving the combustion stratification. In future, combustion stratification at higher loads and different operating condition would be explored. Furthermore, a full optical piston would be used so that the combustion images could be captured at early SOI to facilitate comprehensive stratification analysis.

\section{References}

1. Borgqvist, P., Tunestal, P., and Johansson, B. "Gasoline Partially Premixed Combustion in a Light Duty Engine at Low Load and Idle Operating Conditions," SAE Technical Paper 2012-010687, 2012, doi:10.4271/2012-01-0687.

2. Hardy, W. and Reitz, R. "An Experimental Investigation of Partially Premixed Combustion Strategies Using Multiple Injections in a Heavy-Duty Diesel Engine," SAE Technical Paper 2006-01-0917, 2006, doi:10.4271/2006-01-0917.

3. Andersson, M., Johansson, B., Hultqvist, A., and Noehre, C. "A Predictive Real Time $\mathrm{NO}_{\mathrm{X}}$ Model for Conventional and Partially Premixed Diesel Combustion," SAE Technical Paper 2006-013329, 2006, doi:10.4271/2006-01-3329.

4. Noehre, C., Andersson, M., Johansson, B., and Hultqvist, A. "Characterization of Partially Premixed Combustion," SAE Technical Paper 2006-01-3412, 2006, doi:10.4271/2006-01-3412.

5. Li, C., Yin, L., Shamun, S., Tuner, M. , "Transition from HCCI to PPC: the Sensitivity of Combustion Phasing to the Intake Temperature and the Injection Timing with and without EGR," SAE Technical Paper 2016-01-0767, 2016, doi:10.4271/2016-01-0767.

6. Lewander, C., Johansson, B., and Tunestal, P. "Extending the Operating Region of Multi-Cylinder Partially Premixed Combustion using High Octane Number Fuel," SAE Technical Paper 2011-01-1394, 2011, doi:10.4271/2011-01-1394.

7. Lewander, M., Ekholm, K., Johansson, B., Tunestål, P. , "Investigation of the Combustion Characteristics with Focus on Partially Premixed Combustion in a Heavy Duty Engine," SAE Int. J. Fuels Lubr. 1(1):1063-1074, 2009, doi:10.4271/2008-01-1658.

8. Lu, P., Zhao, H., and Herfatmanesh, M. "In-Cylinder Studies of High Injection Pressure Gasoline Partially Premixed Combustion in a Single Cylinder Optical Engine," SAE Technical Paper 201501-1819, 2015, doi:10.4271/2015-01-1819.

9. Tanov, S., Collin, R., Johansson, B., and Tuner, M. "Combustion Stratification with Partially Premixed Combustion, PPC, using NVO and Split Injection in a LD - Diesel Engine," SAE Int. J. Engines 7(4):1911-1919, 2014, doi:10.4271/2014-01-2677. 
10. Zegers, R., Aussems, J., Somers, L., Dam, N. , "Correlating Flame Location and Ignition Delay in Partially Premixed Combustion," SAE Technical Paper 2012-01-1579, 2012, doi: $10.4271 / 2012-01-1579$.

11. Founti, M., Hardalupas, Y., Hong, C., Keramiotis, C. , "An Experimental Investigation on the Effect of Diluent Addition on Flame Characteristics in a Single Cylinder Optical Diesel Engine," SAE Technical Paper 2015-24-2438, 2015, doi: $10.4271 / 2015-24-2438$.

12. Izadi Najafabadi, M., Dam, N., Somers, B., and Johansson, B. "Ignition Sensitivity Study of Partially Premixed Combustion by Using Shadowgraphy and $\mathrm{OH}^{*}$ Chemiluminescence Methods," SAE Technical Paper 2016-01-0761, 2016, doi:10.4271/2016-01-0761.

13. Kalghatgi, G., Risberg, P., and Ångström, H. "Partially PreMixed Auto-Ignition of Gasoline to Attain Low Smoke and Low $\mathrm{NO}_{X}$ at High Load in a Compression Ignition Engine and Comparison with a Diesel Fuel," SAE Technical Paper 2007-010006, 2007, doi:10.4271/2007-01-0006.

14. Weall, A. and Collings, N. "Investigation into Partially Premixed Combustion in a Light-Duty Multi-Cylinder Diesel Engine Fuelled Gasoline and Diesel with a Mixture of," SAE Technical Paper 2007-01-4058, 2007, doi:10.4271/2007-01-4058.

15. Ahmed, A., Khurshid, M., Naser, N., Badra, J. , "Surrogate fuel formulation for light naphtha combustion in advanced combustion engines", In Proceedings of the European Combustion Meeting, 2015.

16. Chang, J., Viollet, Y., Amer, A., and Kalghatgi, G. "Fuel Economy Potential of Partially Premixed Compression Ignition (PPCI) Combustion with Naphtha Fuel," SAE Technical Paper 2013-01-2701, 2013, doi:10.4271/2013-01-2701.

17. Won, H., Peters, N., Pitsch, H., Tait, N. , "Partially Premixed Combustion of Gasoline Type Fuels Using Larger Size Nozzle and Higher Compression Ratio in a Diesel Engine," SAE Technical Paper 2013-01-2539, 2013, doi:10.4271/2013-01-2539.

18. Akihama, K., Kosaka, H., Hotta, Y., Nishikawa, K. , "An Investigation of High Load (Compression Ignition) Operation of the "Naphtha Engine" - a Combustion Strategy for Low Well-toWheel CO2 Emissions," SAE Int. J. Fuels Lubr. 1(1):920-932, 2009, doi:10.4271/2008-01-1599.

19. Wang, J., Yang, F., and Ouyang, M. "Performance of Naphtha in Different Compression Ignition Combustion Modes under Various EGR Rates," SAE Technical Paper 2015-01-0804, 2015, doi: 10.4271/2015-01-0804.

20. Raman, V., Sivasankaralingam, V., Dibble, R. and Sarathy, S.M. " $\alpha$-Pinene-A High Energy Density Biofuel for SI Engine Applications" SAE Technical Paper 2016-01-2171, 2016, doi:10.4271/2016-01-2171.

21. Leermakers, C., Van den Berge, B., Luijten, C., Somers, L. , "Gasoline-Diesel Dual Fuel: Effect of Injection Timing and Fuel Balance," SAE Technical Paper 2011-01-2437, 2011, doi:10.4271/2011-01-2437.

22. Sang, W., Cheng, W., and Maria, A. "The Nature of Heat Release in Gasoline PPCI Engines," SAE Technical Paper 201401-1295, 2014, doi:10.4271/2014-01-1295.
23. Hildingsson, L., Kalghatgi, G., Tait, N., Johansson, B. , "Fuel Octane Effects in the Partially Premixed Combustion Regime in Compression Ignition Engines," SAE Technical Paper 2009-012648, 2009, doi: 10.4271/2009-01-2648.

24. Solaka, H., Tuner, M., and Johansson, B. "Analysis of Surrogate Fuels Effect on Ignition Delay and Low Temperature Reaction during Partially Premixed Combustion," SAE Technical Paper 2013-01-0903, 2013, doi:10.4271/2013-01-0903.

25. Manente, V., Johansson, B., and Tunestal, P. "Characterization of partially premixed combustion with ethanol: EGR sweeps, low and maximum loads", Journal of Engineering for Gas Turbines and Power, 132(8):082802, 2010, doi: $10.1115 / 1.4000291$.

26. Manente, V., Johansson, B., Tunestal, P., and Cannella, W. "Influence of Inlet Pressure, EGR, Combustion Phasing, Speed and Pilot Ratio on High Load Gasoline Partially Premixed Combustion," SAE Technical Paper 2010-01-1471, 2010, doi:10.4271/2010-01-1471.

27. Kawamoto, K., Araki, T., Shinzawa, M., Kimura, S. , "Combination of Combustion Concept and Fuel Property for Ultra-Clean DI Diesel," SAE Technical Paper 2004-01-1868, 2004, doi: $10.4271 / 2004-01-1868$.

28. An, Y. Z., Teng, S. P., Pei, Y. Q., Qin, J., “An experimental study of polycyclic aromatic hydrocarbons and soot emissions from a GDI engine fueled with commercial gasoline", Fuel, 164:160-171, 2016, doi:10.1016/j.fuel.2015.10.007.

29. An, Y. Z., Pei, Y. Q., Qin, J., Zhao, H. , "Development of a PAH (polycyclic aromatic hydrocarbon) formation model for gasoline surrogates and its application for GDI (gasoline direct injection) engine CFD (computational fluid dynamics) simulation", Energy, 94:367-379, 2016, doi:10.1016/j.energy.2015.11.014.

30. An, Y. Z., Li, X., Teng, S. P., Wang, K. , "Development of a soot particle model with PAHs as precursors through simulations and experiments", Fuel, 179:246-257, 2016, doi:10.1016/j. fuel.2016.03.100.

\section{Contact information}

Dr. R. Vallinayagam

Post-doctoral research fellow

Clean Combustion Research Centre (CCRC)

King Abdullah University of Science and Technology (KAUST)

Thuwal, Saudi Arabia

vallinayagam.raman@,kaust.edu.sa

Phone no - +966 544701225

\section{Acknowledgments}

This work was funded by competitive research funding from King Abdullah University of Science and Technology (KAUST) under the Clean Combustion Research Center's research program. We also acknowledge funding from KAUST and Saudi Aramco under the FUELCOM program. Finally, we would like to express our gratitude to our research Technician, Adrian. I. Ichim for his support in carrying out the experiments at KAUST engine lab. 


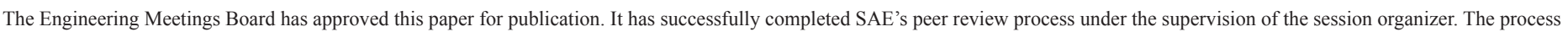
requires a minimum of three (3) reviews by industry experts.

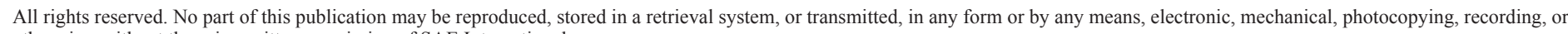
otherwise, without the prior written permission of SAE International.

Positions and opinions advanced in this paper are those of the author(s) and not necessarily those of SAE International. The author is solely responsible for the content of the paper.

ISSN 0148-7191

http://papers.sae.org/2017-01-0745 